\title{
Analisis Kandungan Logam Berat pada Air Sumur Gali Dusun IV Desa Poasaa Kabupaten Konawe
}

\author{
Sri Pina Ariyanti ${ }^{1)}$, Muh anas $^{2)}$, Erniwati $^{2)}$ \\ ${ }^{1}$ Alumni Jurusan Pendidikan Fisika, FKIP Universitas Halu Oleo, Jl. H.E.A Mokodompit, Kendari 93232 \\ ${ }^{2}$ Dosen Jurusan Pendidikan Fisika, FKIP Universitas Halu Oleo, Jl. H.E.A Mokodompit, Kendari 93232 \\ Email: sripina014@gmail.com
}

\begin{abstract}
This study aims to obtain information about the content of Iron (Fe), Manganese (Mn), Lead $(\mathrm{Pb})$, temperature and turbidity in dug well water. The sampling method is performed purposive sampling which is a sampling technique with particular consideration. The number of samples in the study is 3 samples namely 2 clean water well samples and 1 sample of cloudy water wells.The heavy metals content uses determinan by Atomic Absorption Spectroscopy (SSA), turbidi is usesed by turbidimeters and temperature is usesed thermometer. Based on the results of research obtained that for sample A, iron content $(\mathrm{Fe}) 0.071 \mathrm{mg} / \mathrm{L}$, manganese $(\mathrm{Mn})$ $0.052 \mathrm{mg} / \mathrm{L}$ and lead $(\mathrm{PB}) 0.002 \mathrm{mg} / \mathrm{L}$. Subsequent sample B, iron content $(\mathrm{Fe}) 0.163 \mathrm{mg} / \mathrm{L}$, manganese $(\mathrm{Mn}) 0.216 \mathrm{mg} / \mathrm{L}$ and lead $(\mathrm{PB}) 0.020 \mathrm{mg} / \mathrm{L}$. Then sample $\mathrm{C}$ iron content $(\mathrm{Fe}) 1.042$ $\mathrm{mg} / \mathrm{L}$, manganese $(\mathrm{Mn}) 0.964 \mathrm{mg} / \mathrm{L}$ and lead $(\mathrm{PB}) 0.048 \mathrm{mg} / \mathrm{L}$, turbidity obtained at $2.17 \mathrm{NTU}$, 3.85 NTU and 124.86 NTU and temperature obtained at $29^{\circ} \mathrm{c}$. Thereby it can be concluded that sample A has meet the standard standards of quality, then for sample B, the content of iron and manganese has been meet but for the lead does not meet while for sample $\mathrm{C}$ does not meet the requirement of quality standards according to PERMENKES/No. 492/ IV/ 2010.
\end{abstract}

Keyword: Water Dug Wells, Heavy Metal Fe, Mn, Pb, Turbidity, Atomic Absorption Spectroscopy $(A A S)$

\begin{abstract}
Abstrak: Penelitian ini bertujuan untuk memperoleh informasi mengenai kandungan logam Besi $(\mathrm{Fe})$, Mangan $(\mathrm{Mn})$, Timbal $(\mathrm{Pb})$, suhu dan kekeruhan pada air sumur gali. Metode pengambilan sampel dilakukan secara Purposive sampling yaitu teknik atau metode yang penentuan sampel dengan pertimbangan tertentu. Jumlah sampel dalam penelitian ini adalah 3 sampel yaitu 2 sampe untuk air sumur jernih dan 1 sampel untuk air sumur keruh. Penelitian dengan Spektroskopi Serapan Atom (SSA), pemeriksaan kekeruhan menggunakan turbidimeter, sedangkan pemeriksaan suhu dilakukan dengan menggunakan thermometer. Berdasarkan hasil penelitan diperoleh bahwa untuk sampel A kandungan besi (Fe) 0,071 mg/l, Mangan (Mn) $0.052 \mathrm{mg} / \mathrm{l}$, dan Timbal $(\mathrm{Pb})$ 0,002 mg/l, selanjutnya untuk sampel B kandungan Besi (Fe) 0,163 mg/l, Mangan (Mn) 0,126 mg/l dan Timbal $(\mathrm{Pb})$ 0,020 mg/l. Kemudian untuk sampel C kandungan Besi $(\mathrm{Fe})$ $1,042 \mathrm{mg} / \mathrm{l}$, Mangan (Mn) 0,964 mg/l dan Timbal (Pb) 0,048 mg/l, kekeruhan di peroleh sebesar 2,17 NTU, 3,85 NTU dan 124,86 NTU serta suhu diperoleh sebesar $29^{\circ} \mathrm{C}$. Dengan demikian dapat disimpulkan bahwa untuk sampel A telah memenuhi syarat baku mutu, kemudian untuk sampel B, kandungan Besi ( $\mathrm{Fe}$ ) dan Mangan ( $\mathrm{Mn}$ ) telah memenuhi. Namun, pada kandungan timbal tidak memenuhi. Selanjutnya untuk sampel $\mathrm{C}$ tidak memenuhi syarat baku mutu PERMENKES/No. 492/ IV/ 2010.
\end{abstract}

Kata kunci: Air sumur gali, logam berat Fe, Mn, Pb, Kekeruhan, Suhu Spektroskopi Serapan Atom (SSA)

\section{PENDAHULUAN}

Air merupakan media lingkungan yang tidak dapat dipisahkan dari manusia dalam kehidupannya. Namun seiring perkembangan teknologi, pencemaran terhadap lingkungan air terjadi secara besar-besaran yang menyebabkan kualitas air semakin menurun. Lingkungan yang sehat dan tidak tercemar salah satunya dapat dilihat dari kualitas air yang digunakan manusia sebagai pokok 
penunjang aktivitas dalam kehidupan manusia. Air yang digunakan dapat bersumber dari air permukaan maupun air tanah. Dalam penggunaan air untuk konsumsi maupun rumah tangga, air yang digunakan tentunya harus bersih, kualitas air bersih yang digunakan memenuhi syarat kesehatan bebas dari pencemaran (Burgan, 2012).

Namun, air menjadi masalah yang perlu mendapat perhatian yang serius, karena air sudah banyak tercemar oleh bermacammacam limbah dari berbagai hasil kegiatan manusia. Sehingga secara kualitas sumber daya air telah mengalami penurunan. Demikian pula secara kuantitas sudah tidak mampu memenuhi kebutuhan yang terus meningkat (Warlina. L, 2004). Permasalahan yang timbul yakni sering dijumpai bahwa kualitas air tanah yang digunakan masyarakat kurang memenuhi syarat sebagai air minum yang sehat bahkan di beberapa tempat bahkan tidak layak untuk diminum. Air yang layak diminum, mempunyai standar persyaratan tertentu yakni persyaratan fisik, kimiawi dan bakteriologis, dan syarat tersebut merupakan satu kesatuan. Jadi jika ada salah satu parameter saja yang tidak memenuhi syarat maka air tesebut tidak layak untuk diminum.

Sumur gali merupakan sumber air yang banyak dipergunakan masyarakat Indonesia. Sumur gali menyediakan air yang berasal dari lapisan tanah yang relatif dekat dari permukaan tanah. Oleh karena itu, sumur gali sangat mudah terkontaminasi melalui rembesan. Keadaan konstruksi dan cara pengambilan air sumur dapat juga merupakan sumber kontaminasi (Entjang, 2000). Pengambilan air sumur gali yang berlebihan menyebabkan turunnya muka air tanah. Jika keadaan demikian tidak dapat dikendalikan, dapat mengakibatkan zat pencemar asal saluran limbah atau tangki septik yang konstruksinya kurang baik masuk ke dalam akuifer air sumur gali. Dengan demikian, sistem air sumur gali mendapat imbuhan dari perembesan air hujan, dan di daerah pemukiman padat dan sistem sanitasinya tidak baik, atau air dari tangki septik dapat merembes ke dalam ekuifer dan mencemari air sumur gali. Jika keadaan kontruksi sumur tidak saniter, maka peluang terjadinya kontaminasi terhadap air sumur akan besar.

Dalam mencukupi kebutuhan sehari-hari dalam hal sumber daya air, masyarakat Desa Poasaa Dusun IV sebagian besar telah menggunakan fasilitas air bersih sumur gali. Sumur gali digunakan untuk memenuhi kebutuhan seperti mandi, mencuci, memasak, minum dan lain sebagainya. Namun masyarakat sekitar tidak tahu air sumur gali tersebut layak atau tidak layak digunakan sebagai sumber air bersih untuk kebutuhan sehari-hari. Sehingga perlu dilakukan peninjauan kelayakan air sumur di Desa Poasaa Dusun IV. Dari hasil observasi yang dilakukan sebagian air sumur gali masyarakat ada yang berwarna kuning-kecoklatan, keruh, berasa, berbau dan apabila dibiarkan beberapa hari terdapat endapan pada wadah. Menurut Achmad (2004) adanya kandungan besi $(\mathrm{Fe})$ pada air sumur gali menimbulkan rasa yang tidak enak dan berbau pada air tersebut, Hendrawati (2013) mengatakan kandungan mangan (Mn) menimbulkan bau yang kurang enak wadah. Suwardi (2011) mengatakan adanya kandungan logam timbal $\mathrm{Pb})$ dalam ai sumur menyebabkan warna kecoklatan dan berbau logam sehingga menimbulkan keengganan untuk mengkomsumsinya.

Melihat fenomena tersebut, maka sangat penting untuk diadakan suatu penelitian dengan mengkaji lebih dalam mengenai analisis kandungan logam berat air sumur gali sebagai air bersih untuk kebutuha seharihari didesa poasaa dusun IV, agar masyarakat tahu bahwa air sumur gali desa poasaa dusun IV layak digunakan atau tidak.

\section{METODE}

Penelitian telah dilakukan pada Juni 2018 sampai selesai. lokasi penelitian ini adalah di Dusun IV Desa Poasaa Kabupaten Konawe. 
Dilakukan di Laboratorium Forensik Fakultas Matematika dan Ilmu Pengetahuan Alam Universitas Halu Oleo. Penelitian ini termasuk jenis penelitian eksperimen.

\section{Prosedur Penelitian \\ Pengukuran Kekeruhan}

Sampel air sumur di ambil dari botol plastik sebanyak $10 \mathrm{ml}$, kemudian tuangkan ke dalam botol kecil yang akan dimasukkan ke dalam alat turbidymeter. Selanjutnya alat turbidymeter dikalibrasi terlebih dahulu dengan tujuan menjamin tingkat ketelitian dalam pengukuran. Kemudian tekan tombol on/off untuk menghidupkan alat, tunggu hingga layar menyala dan tertera "Rd". Sampel dimasukkan ke dalam botol sampel, kemudian ditutup lalu read ditekan dan ditunggu hingga muncul nilai pada layar.

\section{Pengukuran Suhu}

Sampel air sumur dimasukkan ke dalam gelas kimia masing-masing $10 \mathrm{ml}$. Pengujian dilakukan dengan menggunakan thermometer. Untuk mengetahui suhu air sumur yang terdapat pada gelas kimia tersebut. Pengambilan data dilakukan sebanyak 2 kali.

1. Penentuan Kadar Kandungan Unsur Besi (Fe), Mangan (Mn), dan Timbal (Pb).

a. Preparasi dengan $\left(\mathrm{HNO}_{3}\right)$ pekat $65 \%$

Sampel yang telah diambil tidak dapat segera dianalisis, melainkan terlebih dahulu perlu dilakukan langkah-langkah sebagai berikut.

1) Masing-masing sampel diambil sebanyak $10 \mathrm{ml}$ dimasukkan kedalam beker glass $100 \mathrm{ml}$.

2) Kemudian ditambahkan $2 \mathrm{ml}\left(\mathrm{HNO}_{3}\right)$ pekat $65 \%$.

3) Selanjutnya dipanaskan di Hotplate selama \pm 30 menit sampai larutan sampel menguap.

4) Setelah didinginkan beberapa saat kemudian dimasukkan kedalam labu ukur $100 \mathrm{ml}$, melalui kertas saring whatman No. 40 selanjutnya ditambahkan $25 \mathrm{ml}$ aquades lalu di homogenkan dengan cara dikocok.

b. Pembuatan Larutan Baku Logam Besi $(\mathrm{Fe}), 100 \mathrm{mg} / \mathrm{l}$

1) Dengan menggunakan pipet diambil 5 $\mathrm{ml}$ dari larutan induk besi $1000 \mathrm{mg} / \mathrm{l}$ dimasukkan kedalam labu ukur $50 \mathrm{ml}$.

2) Ditambahkan aquades sampai tanda batas.

c. Pembuatan Larutan Standar Logam Besi (Fe), $10 \mathrm{mg} / \mathrm{l}$

1) Dengan menggunakan pipet diambil 10 $\mathrm{ml}$ dari larutan baku besi $100 \mathrm{mg} / \mathrm{l}$ dimasukkan kedalam labu ukur $100 \mathrm{ml}$.

2) Ditambahkan aquades sampai tanda batas

d. Pembuatan larutan standar logam besi (Fe), $0 \mathrm{mg} / \mathrm{l} ; 0,25 \mathrm{mg} / \mathrm{l} ; 0,5 \mathrm{mg} / \mathrm{l} ; 0,75$ $\mathrm{mg} / \mathrm{l}, 1 \mathrm{mg} / \mathrm{l}, 1,25 \mathrm{mg} / \mathrm{l}$; dan 1,5 mg/l.

1) Dengan menggunakan pipet diambil 0 $\mathrm{ml}, 25 \mathrm{ml}, 5 \mathrm{ml}, 7,5 \mathrm{ml}, 10 \mathrm{ml}, 12,5 \mathrm{ml}$, dan $15 \mathrm{ml}$ dari larutan standar $10 \mathrm{mg} / \mathrm{l}$ dimasukkan kedalam labu ukur $100 \mathrm{ml}$.

2) Menambahkan larutan pengencer sampai tanda batas sehingga diperoleh konsentrasi logam besi (Fe) $0 \mathrm{mg} / \mathrm{l}$, $0,25 \mathrm{mg} / \mathrm{l}, 0,5 \mathrm{mg} / \mathrm{l}, 0,75 \mathrm{mg} / \mathrm{l}, 1 \mathrm{mg} / \mathrm{l}$, $1,25 \mathrm{mg} / \mathrm{l}$ dan $1,5 \mathrm{mg} / \mathrm{l}$.

e. Pengukuran absorbansi larutan standar besi $(\mathrm{Fe})$ dan konsentrasi besi $(\mathrm{Fe})$ dalam sampel SSA.

1) Mengoptimalkan alat SSA sesuai dengan petunjuk penggunaan alat.

2) Kemudian mengukur absorbansi larutan standar (larutan kerja) besi $(\mathrm{Fe})$ dengan konsentrasi $0 \mathrm{mg} / \mathrm{l}$. hal yang sama untuk larutan seri standar 0,25 $\mathrm{mg} / \mathrm{l}, 0,5 \mathrm{mg} / \mathrm{l}, 0,75 \mathrm{mg} / \mathrm{l}, 1 \mathrm{mg} / \mathrm{l}, 1,25$ $\mathrm{mg} / \mathrm{l}$ dan $1,5 \mathrm{mg} / \mathrm{l}$, dilanjutkan dengan membuat kurva kalibrasi untuk mendapatkan persamaan garis regresi.

3) Dilanjutkan dengan pengukuran konsentrasi sampel yang sudah disiapkan.

4) Dengan cara sama di lakukan juga pada logam Mangan $(\mathrm{Mn})$, dan Timbal $(\mathrm{Pb})$. 


\section{HASIL DAN PEMBAHASAN}

Tabel 1. Hasil Analisis Kandungan Kadar Unsur Air Sumur Gali Dusun IV Desa Poasaa Kabupaten Konawe

\begin{tabular}{|c|c|c|c|c|c|c|c|}
\hline \multirow[b]{2}{*}{ No } & \multirow[b]{2}{*}{ Parameter } & \multirow[b]{2}{*}{ Satuan } & \multicolumn{3}{|c|}{ Konsentrasi tiap Sampel } & \multirow{2}{*}{$\begin{array}{l}\text { Standar } \\
\text { Mutu } \\
\text { Minum) }\end{array}$} & \multirow{2}{*}{$\begin{array}{lr}\text { Standar } & \text { buku } \\
\text { Mutu } & \text { (air } \\
\text { bersih) }\end{array}$} \\
\hline & & & A & B & C & & \\
\hline 1 & Suhu & ${ }^{\circ} \mathrm{C}$ & 29 & 29 & 29 & $\leq 30^{\circ} \mathrm{C}$ & $\leq 30^{\circ} \mathrm{C}$ \\
\hline 2 & Kekeruhan & NTU & 2.17 & 3.85 & 124.86 & $\leq 5 \mathrm{NTU}$ & $\leq 25 \mathrm{NTU}$ \\
\hline 3 & Besi $(\mathrm{Fe})$ & $\mathrm{mg} / \mathrm{l}$ & 0.071 & 0.163 & 1.042 & $\leq 0.3 \mathrm{mg} / 1$ & $1.0 \mathrm{mg} / 1$ \\
\hline 4 & Mangan (Mn) & $\mathrm{mg} / \mathrm{l}$ & 0.052 & 0.126 & 0.964 & $\leq 0.5 \mathrm{mg} / 1$ & $0.5 \mathrm{mg} / \mathrm{l}$ \\
\hline 5 & Timbal $(\mathrm{Pb})$ & $\mathrm{mg} / \mathrm{l}$ & 0.002 & 0.020 & 0.048 & $\leq 0.01 \mathrm{mg} / 1$ & $0.05 \mathrm{mg} / \mathrm{l}$ \\
\hline
\end{tabular}

Dari Tabel menunjukkan bahwa untuk sumur A telah memenuhi standar baku mutu baik untuk kualitas air minum maupun air bersih, selanjutnya untuk sumur B tidak memenuhi standar untuk kualitas air bersih tetapi, memenuhi standar baku mutu untuk kualitas air minum. Sedangkan untuk sumur C keduanya tidak memenuhi baik untuk air minum maupun air bersih.

Dusun IV merupakan salah satu dari 4 dusun Desa Poasaa Kecamatan Unaaha Kabupaten Konawe. Masyarakat Desa Poasaa Dusun IV sebagian besar penduduknya adalah petani. Masyarakat Dusun IV Desa Poasaa dalam memenuhi kebutuhan sehari-hari dalam hal sumber daya air sperti mandi, mencuci, memasak dan minum masih menggunakan air sumur gali sebagai sumber utama. Air sumur gali yang digunakan warga sebagai sumber air ini merupakan sumur gali umum yang digunakan secara bersama-sama oleh sebagian besar masyarakat meskipun ada sebagian yang memiliki sumur pribadi. Jumlah sumur yang dijadikan sebagai sumber air berjumlah 25 sumur namun hanya 3 sumur yang digunakan secara bersama-sama oleh masyarakat.

Sumur gali C memiliki konsentrasi logam yang lebih tinggi dibanding dengan sumur gali A dan B, hal ini disebabkan beberapa faktor yaitu jarak jamban ke sumur gali, konstruksi sumur gali, struktur dan jenis tanah dan umur sumur gali. Jarak antara jamban dengan sumur gali berpengaruh terhadap kualitas dari sumur gali tersebut. Hal ini sejalan dengan penelitian yang dilakukan oleh Marsono (2009) menyatakan bahwa sampel sumur yang memiliki jarak dengan sumber pencemar kurang dari 10 meter maka tidak memenuhi syarat. Menurut Rahayu Sri Pujianti dan Dwi Ochta Pebriyanti (2010) menyatakan bahwa ada pengaruh yang signifikan antara jarak sumur gali dengan jarak jamban terhadap air sumur gali. Maria (2014) mengatakan bahwa sumur gali yang berjarak kurang dari 10 meter dari sumber pencemar, mempunyai resiko tercemarnya air sumur oleh perembesan air dari sumber pencemar. Hal ini dapat disimpulkan bahwa jarak jamban merupakan faktor resiko kualitas air sumur gali. Sumur gali C memiliki struktur tanah liat dan jenis tanah berpasir yang porositasnya besar sehingga air hasil buangan dari sumber pencemar mudah meresap dan kondisi demikian akan mempermudah air sumur gali tercemar. Kualitas tanah juga mempengaruhi pencemaran air, ini berkaitan dengan pencemaran tanah yang terjadi di dekat sumber air, beberapa sumber pencemar tanah dapat berupa bahan beracun seperti peptisida, logam berat dan penimbunan sampah secara besar-besaran (Mukono, 2000). 
Analisis kandungan logam ini sangat penting untuk dilakukan mengingat dampak yang dapat ditimbulkannya sangat berbahaya bagi kesehatan manusia. Dampak negatif yang dapat ditimbulkan logam besi $(\mathrm{Fe})$ menyebabkan gangguan kesehatan yaitu bersifat toksis terhadap organ melalui gangguan secara fisiologis, misalnya kerusakan dinding usus. Kadar logam mangan yang tinggi juga dapat menimbulkan gangguan kesehatan seperti serangan jantung, gangguan pembuluh darah bahkan kanker hati (Wardhana, 2004). Dampak dari tingginya kadar logam timbal $(\mathrm{Pb})$ pada air sumur yakni dapat meracuni tubuh manusia baik secara akut maupun kronis (Sudarmadji, 2006).

Untuk mengurangi konsentrasi logam besi $(\mathrm{Fe})$, Mangan $(\mathrm{Mn})$ dan Timbal $(\mathrm{Pb})$ dapat dilakukan dengan berbagai cara. Berdasarkan penelitian yang dilakukan oleh Laila (2014) dengan judul Studi Penurunan Kadar Besi (Fe) Dan Mangan (Mn) Dalam Air Tanah Menggunakan Saringan Keramik, hasil penelitian menunjukkan bahwa air yang dihasilkan dengan menggunakan saringan keramik mampu mereduksi kandungan besi hingga 95,20\% dan mangan sebesar 94,63\%. Air tanah yang dilewati melalui saringan keramik telah memenuhi parameter. Menurut Dahlia (2017) upaya menurunkan kadar logam besi (Fe) pada air sumur dengan menggunakan arang ampas tebu dengan hasil penelitian menunjukkan bahwa kadar ion logam besi $(\mathrm{Fe})$ pada sampel yaitu 0,1683 ppm, waktu kontsk optimum pada adsorpsi ion logam besi $(\mathrm{Fe})$ yaitu pada waktu kontak 120 menit yang menghasilkan efisiensi adsorpsi optimum pada logam besi $(\mathrm{Fe})$ yaitu $65,83 \%$.

\section{KESIMPULAN}

Dari hasil penelitian dan pembahasan diatas dapat disimpulkan bahwa sumur A dan sumur B telah memenuhi standar baku mutu PERMENKES/No. 492/ IV/ 2010 sedangkan sumur $\mathrm{C}$ tidak memenuhi standar baku mutu dengan kandungan logam diperoleh sebesar
Besi (Fe) 1,042 mg/l, Mangan (Mn) 0,964 $\mathrm{mg} / \mathrm{l}$ dan Timbal (Pb) 0,048 mg/l.

\section{DAFTAR PUSTAKA}

Achmad, R. 2004. Kimia lingkungan. Yogyakarta: penerbit Andi.

Burgan. 2012. Air Memberi Minum Dunia yang Dahaga. Gramedia. Jakarta.

Dahlia. R. I, Hendrawani. 2017. Upaya Menurunkan Kadar Ion Logam Besi Pada Air Sumur Dengan Memanfaatkan Arang Ampas Tebu. Hydrogen: Jurnal Kependidikan Kimia. Vol 5 No 2.

Entjang, I. 2000. Ilmu Kesehatan Masyarakat. Penerbit Citra Aditya Bakti, Bandung.

Hendrawati. 2013. Penggunaan Biji Jawa (Tamarindus indica L.) dan Biji Kecipir (Psophocarpus tetragonolobus L.) sebagai Koagulan Alami dalam Perbaikan Kualitas Air Tanah. Prosiding Semirata FMIPA Universitas Lampung, Lampung.

Laila, F. Astrid, A. 2014. Studi Penurunan Kadar Besi (Fe) dan Mangan (Mn) Dalam Air Tanah Menggunakan Saringn Keramik. Jurnal Teknologi. Vol 7 No 1.

Marsono. 2009. Faktor-faktor yang Berhubungan dengan Kualitas Air Sumur Gali Di Pemukiman (Studi Di Desa Karanganon, Kecamatan Klaten Utara, Kabupaten Klaten). Universitas Dipenogoro. Semarang.

Mukono. 2000. Prinsip Dasar Kesehatan Lingkungan. Airlangga University Press. Surabaya

Pebrianti. 2010. Resiko Pencemaran Air Sumur Gali Kelurahan Karang Berombak. Kotamadya Medan.

Rizka M, Dedi M, Hilda L, dan Khori S. 2014. Pengaruh Kondisi Lingkungan Terhadap Kualitas Air Tanah Bebas di Pangalengan Kabupaten Bandung. Pusat Penelitian Geoteknologi LIPI. Bandung.

Sudarmadji. J. Mukono, I.P. Corie. 2006. Toksikologi Logam berat B3 dan dampaknya terhadap kesehatan. Jurnal Kesehatan Lingkungan. 
Jurnal Penelitian Pendidikan Fisika, Vol. 5 No.1 Januari 2020, 72-77

Available Online at http://ojs.uho.ac.id/index.php/JIPFI p-ISSN: 2502-3861 | e-ISSN: 2715-551X

Wardhana, W.A. 2004. Dampak Pencemaran Lingkungan Cetakan Keempat. Yogyakarta: Penerbit ANDI.
Warlina, I. 2004. Pencemaran Air Sumber, Dampak dan Penanggulangannya. Institut Teknologi Bogor. 